\title{
Imidazobenzimidazole hydrochloride derivatives as steel inhibitors in hydrochloric acid
}

\author{
A.G. Berezhnaya, ${ }^{1} *$ V.V. Chernyavina ${ }^{1}$ and L.M. Astakhova ${ }^{2}$ \\ ${ }^{1}$ Southern Federal University, ul. Zorge 7, Rostov-on-Don, 344090 Russian Federation \\ ${ }^{2}$ Don State Technical University, Gagarin square 1, Rostov-on-Don, 344000 Russian \\ Federation \\ *E-mail: berezhnaya-aleksandra@mail.ru
}

\begin{abstract}
The influence of substituted 2-(4-fluorophenyl)-9-R-imidazo[1,2-a]benzimidazole hydrochloride (where $\mathrm{R}=-\mathrm{CH}_{3}(\mathbf{1}),-\mathrm{C}_{2} \mathrm{H}_{5}(\mathbf{2}),-\mathrm{C}_{2} \mathrm{H}_{4} \mathrm{~N}\left(\mathrm{C}_{2} \mathrm{H}_{5}\right)_{2}(\mathbf{3}),-\mathrm{C}_{3} \mathrm{H}_{7}(\mathbf{4}),-\mathrm{C}_{4} \mathrm{H}_{9}(\mathbf{5})$ ) on the corrosion of low carbon steel in $1 \mathrm{M}$ hydrochloric acid solution was studied by gravimetric, temperature-kinetic, polarization, and impedance spectroscopy methods. It was found that the substances studied are effective inhibitors of acid corrosion of low carbon steel. It was shown that the protective effect of substituted imidazobenzimidazole hydrochlorides depends on the nature of the radical $(\mathrm{R})$. Based the protective effect values, the radicals can be arranged in the series: methyl $>$ ethyl $\approx$ butyl $>N, N$-diethylethyleneamine $\approx$ propyl. The protective effect of the compounds depends on the concentration and temperature. It was established that the protective effect of compounds $\mathbf{2}-\mathbf{5}$ increases with increasing temperature. It was shown that the degree of coverage of the steel surface with inhibitors $\mathbf{2}-\mathbf{5}$ increases with temperature. These additives reduce the effective activation energy of the corrosion process. The investigated imidazobenzimidazole derivatives affect the partial electrode reactions of the corrosion process. At the lowest concentration, additives 1-4 reduce the rate of the cathodic and anodic reactions. Additive $\mathbf{5}$ reduces the cathodic reaction rate and stimulates the dissolution of steel. Introduction of organic additives into the acid leads to a decrease in the corrosion potential of steel.
\end{abstract}

Keywords: inhibitor, corrosion, low carbon steel, imidazobenzimidazole hydrochloride derivatives.

Received: January 23, 2020. Published: February 18, 2020

doi: $\underline{10.17675 / 2305-6894-2020-9-1-20}$

\section{Introduction}

Derivatives of imidazobenzimidazole and benzimidazole are often investigated as acid corrosion inhibitors of steel [1-9]. However, data on the effect of imidazobenzimidazole derivatives on corrosion of low-carbon steel in hydrochloric acid solutions are limited. The purpose of this work is to study the effect of 2-(4-fluorophenyl)-9-R-imidazo[1,2a] benzimidazole hydrochloride on corrosion of low-carbon steel in $1 \mathrm{M}$ hydrochloric acid as well as to determine the mechanism of their protective action. 


\section{Experimental}

Samples for polarization and corrosion measurements were cut from low carbon steel. Before measurements, the samples were cleaned with an abrasive paper, degreased with ethanol, washed with distilled water, and dried with filter paper. Studies were carried out in $1 \mathrm{M}$ hydrochloric acid solution.

As inhibitors, substituted 2-(4-fluorophenyl-9-R-imidazo[1,2-a]benzimidazole hydrochlorides (where $\mathrm{R}=-\mathrm{CH}_{3}(\mathbf{1}),-\mathrm{C}_{2} \mathrm{H}_{5}(\mathbf{2}),-\mathrm{C}_{2} \mathrm{H}_{4} \mathrm{~N}\left(\mathrm{C}_{2} \mathrm{H}_{5}\right)_{2}(\mathbf{3}),-\mathrm{C}_{3} \mathrm{H}_{7}(\mathbf{4}),-\mathrm{C}_{4} \mathrm{H}_{9}$ (5)) were studied in the concentration range of $0.01-0.1 \mathrm{mMol} / \mathrm{l}$.

Gravimetric and polarization measurements were carried out according to the traditional method [10]. Potentials in the work are given in relation to the silver chloride electrode.

The effect of inhibitors was evaluated by the process inhibition coefficient $\gamma(1)$ and the degree of protection $Z(2)$ :

$$
\begin{gathered}
\gamma=X_{0} / X_{\mathrm{i}} \\
Z=\frac{\left(X_{0}-X_{i}\right) 100 \%}{X_{0}}
\end{gathered}
$$

where $X_{0}$ and $X_{\mathrm{i}}$ are the rate of corrosion or partial electrode reactions in hydrochloric acid without and in the presence of an inhibitor, respectively.

Capacitive measurements were carried out in 2-electrode cell using a Z-Pack-2 impedance meter (Elins LLC, Russia) at frequencies of $50 \mathrm{mHz}-500 \mathrm{kHz}$ at the corrosion potential. The auxiliary electrode was a cylindrical platinum electrode.

The degree of coverage of the electrode surface $(\Theta)$ was calculated by the formula:

$$
\Theta=\left(C_{0}-C_{i}\right) / C_{0}
$$

where $C_{0}, C_{i}$ are the capacities of the double electric layer (CDL) in the acid solution without and with the inhibitor, respectively.

\section{Results and Discussion}

The data of corrosion measurements obtained at a temperature of $25^{\circ} \mathrm{C}$ in a $1 \mathrm{M}$ solution of hydrochloric acid are presented in Table 1.

As it can be seen from the table, the protective effect of the substituted imidazobenzimidazole hydrochlorides depends on the nature of the radical. By the magnitude of the protective effect, the radicals can be arranged in the series: methyl > ethyl $\approx$ butyl $>N, N$-diethylethyleneamine $\approx$ propyl. An increase in the length and degree of branching of the radical does not unambiguously affect the inhibition coefficient. The linear dependence of the logarithm of the coefficient of inhibition on the logarithm of the concentration of the additive indicates a significant contribution of blocking to the mechanism of action of inhibitors, Figure 1. 
Table 1. Dependence of the inhibitor factor on the additive nature and concentration.

\begin{tabular}{cccccc}
\hline \multirow{2}{*}{$\begin{array}{c}\text { Additive } \\
\text { number }\end{array}$} & \multicolumn{5}{c}{$\boldsymbol{\gamma}$ for $\boldsymbol{C}, \mathbf{m o l} / \mathbf{l}$} \\
\cline { 2 - 6 } & $\mathbf{0 . 1 0}$ & $\mathbf{0 . 0 7 5}$ & $\mathbf{0 . 0 5}$ & $\mathbf{0 . 0 2}$ & $\mathbf{0 . 0 1}$ \\
\hline 1 & 46.56 & 40.6 & 31.9 & 8.4 & 2.4 \\
2 & 6.0 & 4.9 & 4.8 & 1.4 & 1.1 \\
3 & 3.7 & 2.7 & 1.3 & 2.1 & 1.0 \\
4 & 2.4 & 1.9 & 1.0 & 1.2 & 1.0 \\
5 & 5.7 & 4.5 & 3.5 & 2.3 & 1.7 \\
\hline
\end{tabular}

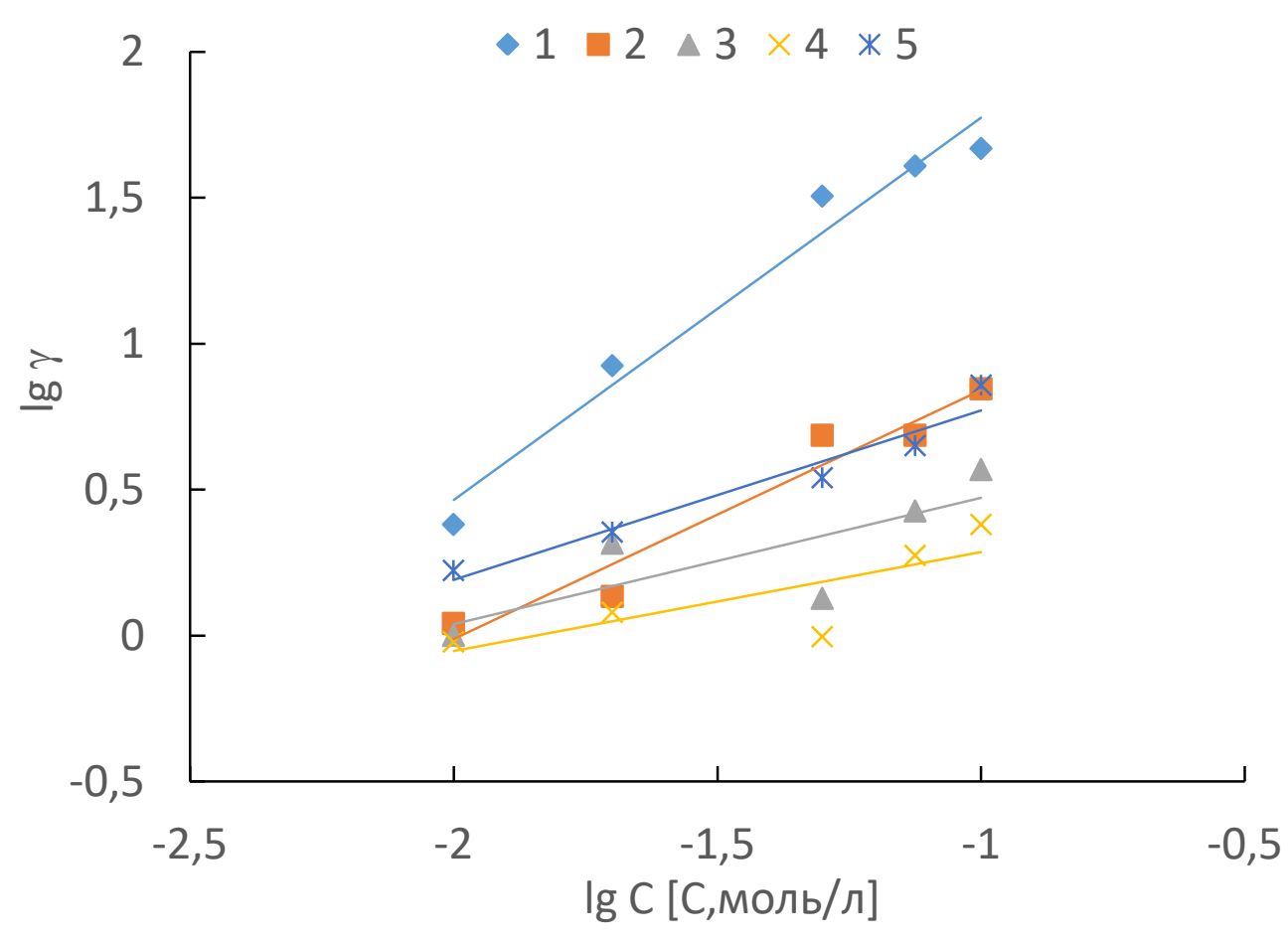

Figure 1. Dependence of the inhibition coefficient of additives on their concentration. The numbers here and in the figures below are the numbers of inhibitors.

The protective effect of the studied inhibitors is significantly dependent on temperature, Figure 2.

With an increase in temperature from 313 to $363 \mathrm{~K}$, the protective effect of the first additive remains almost unchanged, while other compounds have a protective effect. The values of the effective activation energy of the corrosion process $\left(E_{\mathrm{a}}\right)$ and the correlation coefficients of the Arrhenius dependence $(R)$ are presented in Table 2. 


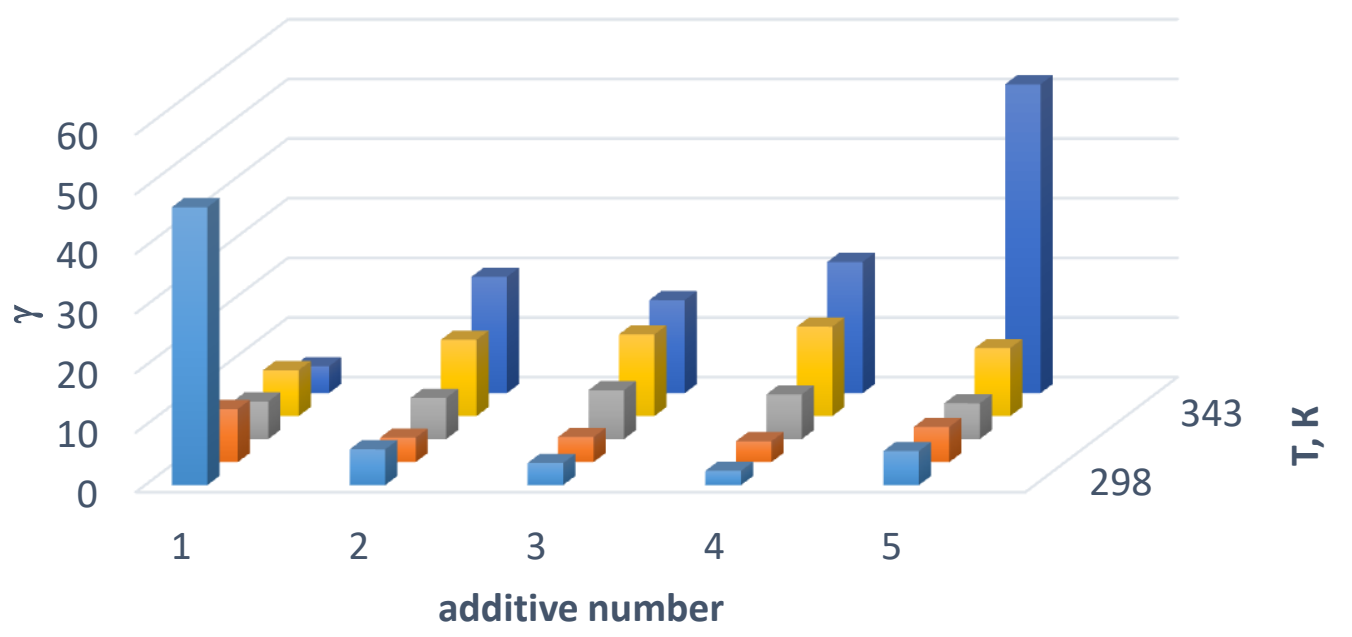

$298 \square 313 \square 333 \square 343 \quad 363$

Figure 2. Dependence of $\gamma$ on the temperature and additive nature, $C=0.1 \mathrm{~mol} / \mathrm{l}$.

Table 2. Values of $E_{a}$ and $R$ depending on the nature of the additive

\begin{tabular}{ccccccc}
\hline $\begin{array}{c}\text { Additive } \\
\text { number }\end{array}$ & $\mathbf{0}$ & $\mathbf{1}$ & $\mathbf{2}$ & $\mathbf{3}$ & $\mathbf{4}$ & $\mathbf{5}$ \\
\hline$E_{\mathrm{a}}, \mathrm{kJ} / \mathrm{mol}$ & 37.4 & 60.3 & 23.9 & 17.9 & 10.5 & 10.8 \\
$R, \%$ & 98.9 & 98.1 & 98.7 & 95.4 & 94.8 & 79.3 \\
\hline
\end{tabular}

The value of $E_{\mathrm{a}}$ in the presence of additives $\mathbf{2}-\mathbf{5}$ decreases compared with the acid solution, which can be caused by an increase in the degree of surface coverage with an inhibitor with temperature. The data of impedance spectroscopy at a temperature of $293 \mathrm{~K}$ are presented in Figure 3.

The obtained hodographs are satisfactorily described by an equivalent circuit consisting of a solution resistance $\left(R_{1}\right)$, a capacitor (double layer capacitance, $C$ ) and charge transfer resistance (polarization resistance, $R_{2}$ ). The capacitance is connected in parallel with the charge transfer resistance. The calculated parameters of the circuit are shown in Table 3.

With the introduction of additives, the resistance of the electrolyte practically does not change. The charge transfer resistance in the presence of additives increases in most cases, and the radius of the circle in the Nyquist diagram also increases. This indicates inhibition by the inhibitors of the corrosion process. Inhibitors reduce the capacity of the double electric layer, which allows us to calculate the degree of surface coverage. The degree of surface coverage actually increases with increasing temperature, Figure 4. 


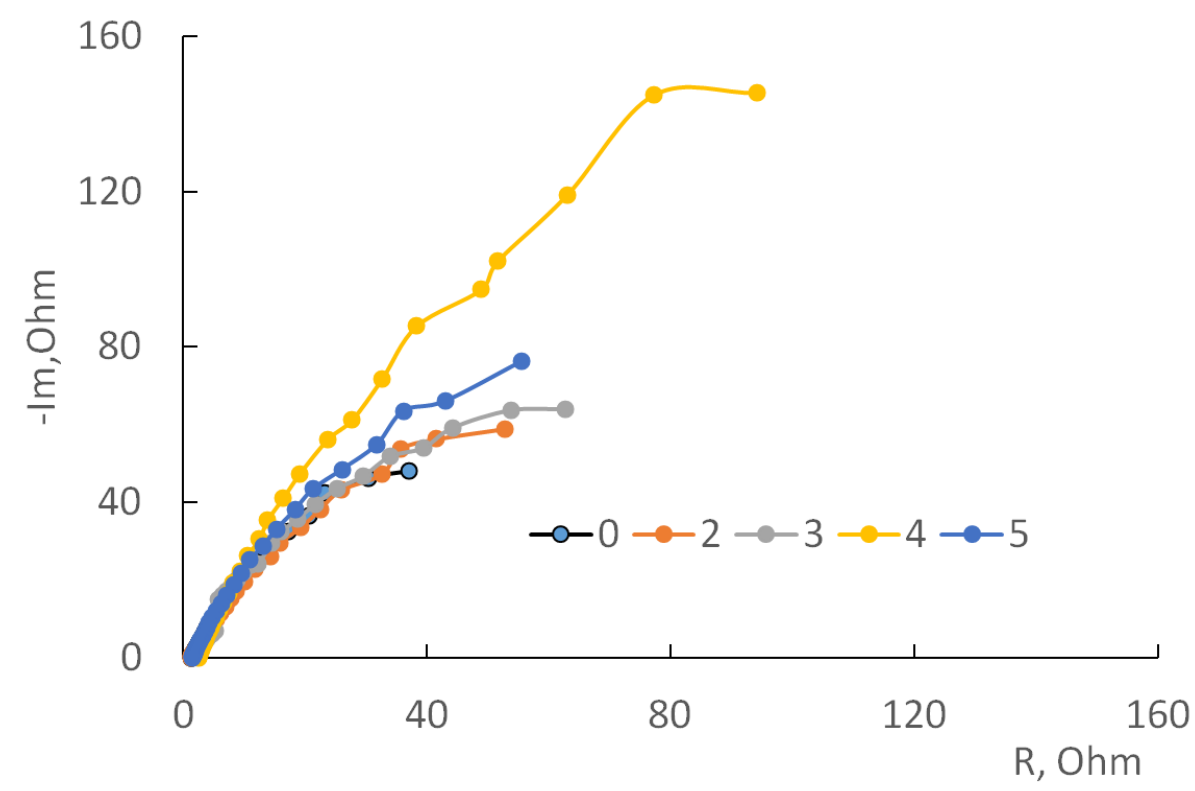

Figure 3. Nyquist diagrams of the electrode in hydrochloric acid without (0) and in the presence of additives $(\mathbf{2}-\mathbf{5}), T=293 \mathrm{~K}$.

Table 3. Equivalent circuit parameters.

\begin{tabular}{cccccc}
\hline & \multicolumn{5}{c}{ Parameter value for additive } \\
\cline { 2 - 6 } Parameter & $\mathbf{0}$ & $\mathbf{2}$ & $\mathbf{3}$ & $\mathbf{4}$ & $\mathbf{5}$ \\
\hline$C \cdot 10^{5}, \mathrm{~F}$ & 3.04 & 1.90 & 1.48 & 1.05 & 1.93 \\
$R_{1}, \mathrm{Ohm}$ & 1.58 & 1.62 & 2.11 & 2.93 & 1.75 \\
$R_{2}, \mathrm{Ohm}$ & 85.02 & 91.66 & 78.0 & 266.20 & 124.00 \\
\hline
\end{tabular}

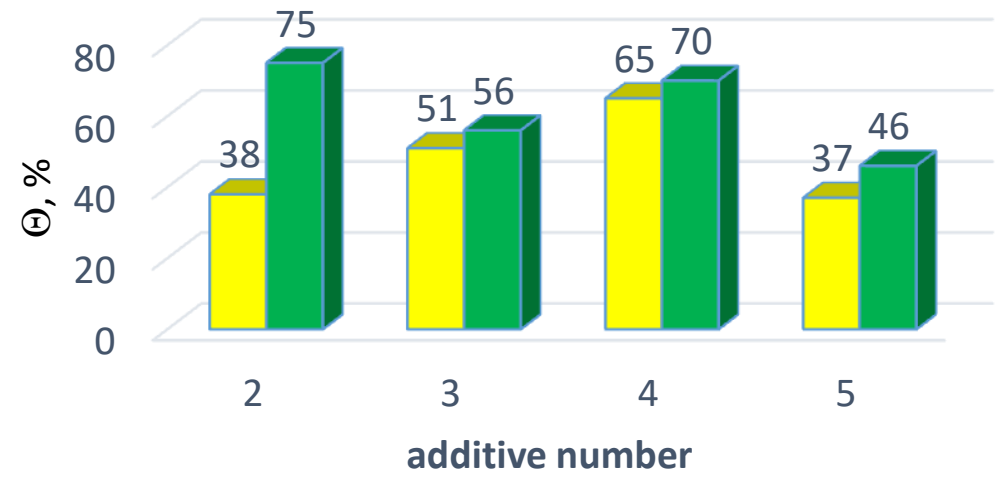

$\square 293 \square 303$

Figure 4. Dependence of the degree of surface coverage $\Theta$ on the additive nature and the temperature. 
To establish the effect of the studied additives on the partial electrode reactions of the corrosion process, polarization curves were taken, Figure 5.
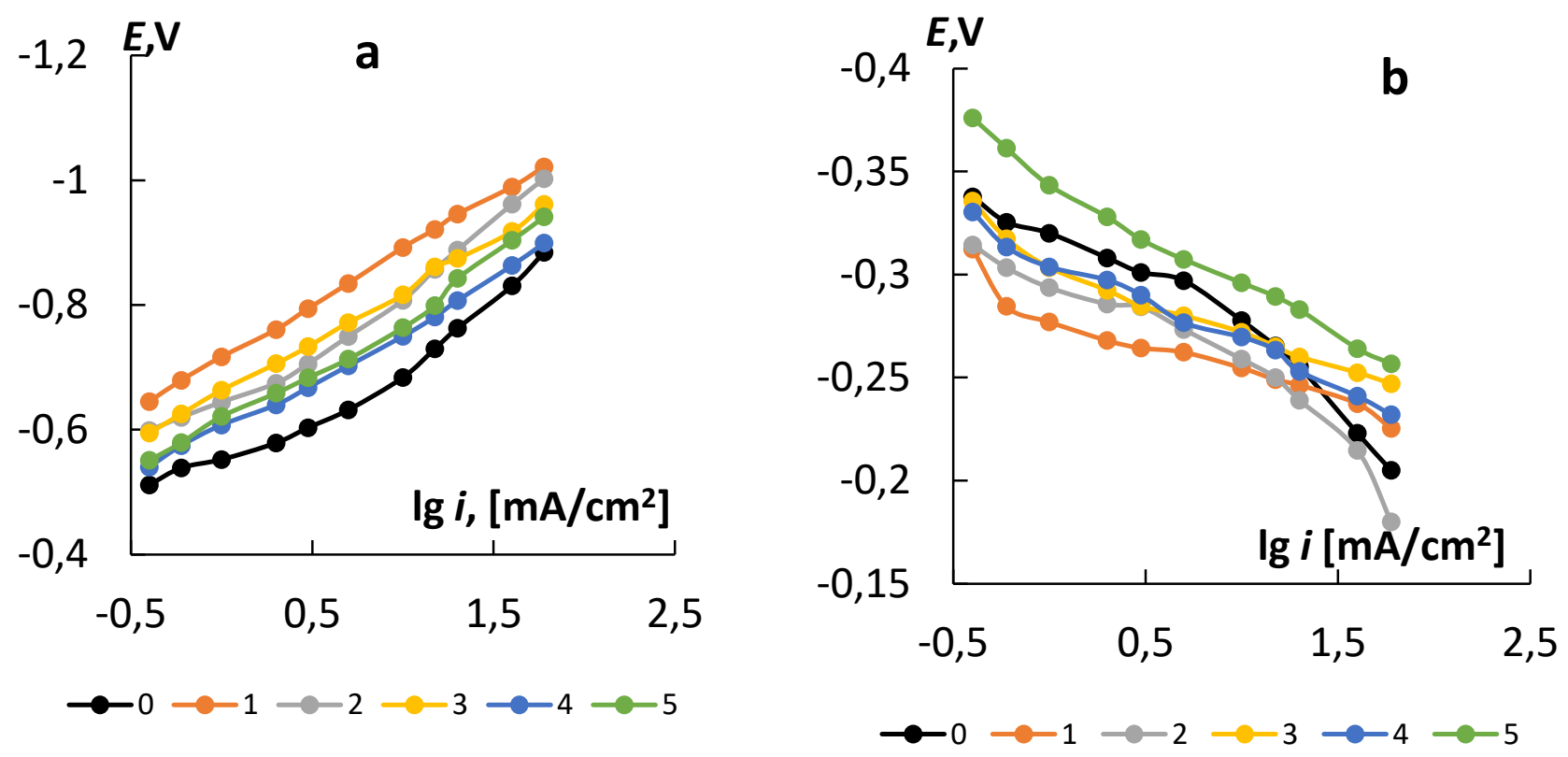

Figure 5. Cathodic (a) and anodic (b) polarization curves of the electrodes in pure hydrochloric acid (0) and in the presence of additives (1-5), $C=0.01 \mathrm{~mol} / \mathrm{l}$.

All the compounds reduce the corrosion potential. Additives 1-4 have an inhibitory effect on the cathodic evolution of hydrogen and the dissolution of steel. Compound $\mathbf{5}$ inhibits the evolution of hydrogen and, at a concentration of $0.01 \mathrm{~mol} / \mathrm{l}$, stimulates the dissolution of steel.

\section{Conclusions}

1. All additives reduce the corrosion rate of steel in hydrochloric acid, regardless of their concentration. The best inhibitory effect is manifested at a concentration of $0.1 \mathrm{mmol} / \mathrm{l}$.

2. The compounds are mixed-type inhibitors with a predominant effect on the rate of the cathodic reaction.

3. The mechanism of action of additives is activation-blocking, with a predominance of blocking component.

\section{References}

1. A. Popova, M. Christov, S. Raicheva and E. Sokolova, Adsorption and inhibitive properties of benzimidazole derivatives in acid mild steel corrosion, Corros. Sci., 2004, 46, no. 6, 1333-1350. https://doi.org/10.1016/j.corsci.2003.09.025

2. S.P. Shpanko, V.P. Grigoriev, E.V. Plekhanova and V.A. Anisimova, Inhibitory and residual protective effect of a benzimidazole derivative in acid corrosion of iron, Phys. Chem. Surf. Prot. Mater., 2010, 46, 225-260. doi: 10.1134/S2070205110020139 
3. H.R. Obayes, G.H. Alwan, A.H. MJ Alobaidy, A.A. Al-Amiery, A.A.H. Kadhum and A.B. Mohamad, Quantum chemical assessment of benzimidazole derivatives as corrosion inhibitors, Chem. Cent. J., 2014, 8, no. 1, 21. doi: 10.1186/1752-153X-8-21

4. S.P. Shpanko, V.P. Grigoriev, E.V. Plekhanova and V.A. Anisimova, Derivatives of imidazo [1,2-a] benzimidazole as corrosion inhibitors of certain metals in an acid solution, Korroz.: mater., zashch., 2015, no. 3, 17-21 (in Russian).

5. S.P. Shpanko, V.P. Grigoriev, E.V. Plekhanova, V.A. Anisimova, I.E. Tolpygin and O.V. Moskaeva, The influence of the structure of acylmethyl derivatives of nitrogencontaining heterosystems on the parameters of acid corrosion of mild steel, Korroz.: mater., zashch., 2014, no. 8, 28-34 (in Russian).

6. S.P. Shpanko, V.P. Grigoriev, V.A. Anisimova, E.V. Plekhanova and I.E. Tolpygin, Synthesis and study of new organic corrosion inhibitors of iron, Korroz.: mater., zashch., 2012, no. 9, 34-39 (in Russian).

7. V.P. Grigoriev, S.P. Shpanko, E.V. Plekhanova, A.S. Burlov and V.A. Anisimova, Using the Pearson concept for the interpretation of the dependence of the duration of the residual protective effect of organic inhibitors on the nature of the metal and anion, Korroz.: mater., zashch., 2011, no. 4, 39-43 (in Russian).

8. S.P. Shpanko, V.P. Grigoriev, E.V. Plekhanova and V.A. Anisimova, Effect of the anion nature and concentration on the mechanism of the residual protective effect of an organic inhibitor of iron corrosion in sulfuric acid, Korroz.: mater., zashch., 2009, no. 8, 34-38 (in Russian).

9. I. Ahamat and M.A. Quraishi, Bis (benzimidazol-2-yl) disulphide: an efficient water soluble inhibitor for corrosion of mild steel in acid media. Corrosю Sci., 2009, 51, no. 9, 2006-2013. doi: $10.1016 /$ j.corsci.2009.05.026

10. A.G. Berezhnaya, GH.A.H. Shayea and V.V. Chernyavina, Mixtures of substituted pyridinium perchlorates with sulfur-containing organic compounds as inhibitors of acid corrosion of steel, Int. J. Corros. Scale Inhib., 2017, 6, no. 4, 372-383. doi: $\underline{10.17675 / 2305-6894-2017-6-4-2}$ 